\title{
POLYPHENOLS AND ANTIOXIDANT ACTIVITY OF FOUR FRUITS NATIVE TO THE COAST OF CEARA UNDER DIFFERENT MATURATION STAGES ${ }^{1}$
}

\author{
NIGÉRIA PEREIRA GONÇALVES², ELISEU MARLÔNIO PEREIRA DE LUCENA ${ }^{3}$, \\ ORIEL HERRERA BONILLA ${ }^{4}$, MÁRCIA RÉGIA SOUZA DA SILVEIRA ${ }^{5}$
}

\begin{abstract}
This study aimed to quantify polyphenolic compounds and antioxidant activity of four fruits native to the coast of Ceara under different maturation stages aiming their use for a healthier diet. Myrtle (Eugenia punicifolia (Kunth) DC.) fruits were collected at the Botanical State Park of Ceara, in Caucaia-CE and guajiru (Chrisobalanus icaco L.), manipuça (Mouriri cearensis Huber) and murici-pitanga (Byrsonima gardneriana A. Juss.) fruits were collected at the Botanical Garden of São Gonçalo, São Gonçalo do Amarante-CE. Fruits were collected and transported to the Laboratory of Plant Ecophysiology, being characterized, processed and frozen for chemical assessments at the Laboratory of Physiology and Postharvest Technology - Embrapa Agroindústria Tropical: polyphenolic compounds and total antioxidant activity. The ESTAT software was used for statistical analyses. The polyphenolic content had the highest and the lowest value for guajiru fruits with 480.73 and $10.90 \mathrm{mg} / 100 \mathrm{~g}$, respectively and total antioxidant activity, the highest value was found for manipuça fruits, with $42.99 \mu \mathrm{M}$ of Trolox/g of pulp and the lowest value for guajiru fruits, with $1.45 \mu \mathrm{M}$ of Trolox/g of pulp. There was a significant correlation between polyphenolic content and total antioxidant activity obtained for guajiru fruits, which showed high correlation coefficient, $\mathrm{R}=-0.95(\mathrm{P}<0.05)$.
\end{abstract}

Index terms: Eugenia punicifolia, Chrisobalanus icaco, Mouriri cearensis, Byrsonima gardneriana.

\section{POLIFENÓLICOS E ATIVIDADE ANTIOXIDANTE DE QUATRO FRUTAS NATIVAS DO LITORAL CEARENSE EM DIFERENTES ESTÁDIOS DE MATURAÇÃO}

RESUMO - A presente pesquisa objetivou quantificar os compostos polifenólicos e a atividade antioxidante de quatro frutas nativas do litoral cearense, em diferentes estádios de maturação, visando a sua utilização para uma alimentação mais saudável. Os frutos da murta (Eugenia punicifolia (Kunth) DC.) foram colhidos no Parque Estadual Botânico do Ceará, em Caucaia-CE, e os do guajiru (Chrisobalanus icaco L.), do manipuçá (Mouriri cearensis Huber) e do murici-pitanga (Byrsonima gardneriana A. Juss.), no Jardim Botânico de São Gonçalo, em São Gonçalo do Amarante-CE. Os frutos foram coletados e transportados ao Laboratório de Ecofisiologia Vegetal, sendo caracterizados, depois processados e congelados para as avaliações químicas, no Laboratório de Fisiologia e Tecnologia Pós-Colheita, da Embrapa Agroindústria Tropical: compostos polifenólicos e atividade antioxidante total. Utilizou-se o programa ESTAT nas análises estatísticas. O teor de polifenólicos teve o maior e o menor valor para o fruto de guajiru, com 480,73 e 10,90 mg/100 g, respectivamente, e à atividade antioxidante total, o maior valor foi no fruto do manipuçá, com $42,99 \mu \mathrm{M}$ de Trolox/g de polpa, e o menor valor, no fruto do guajiru, com 1,45 $\mu \mathrm{M}$ de Trolox/g de polpa. Observou-se correlação significativa e negativa entre os polifenólicos e a atividade antioxidante total obtidos nos frutos do guajiru, que apresentou alto coeficiente de correlação, $\mathrm{R}=-0,95(\mathrm{P}<0,05)$.

Termos para indexação: Eugenia punicifolia, Chrisobalanus icaco, Mouriri cearensis, Byrsonima gardneriana.

${ }^{1}$ (Paper 157-15). Received June 15,2015. Accepeted November 15, 2015.

${ }^{2}$ Master in Natural Resources, State University of Ceará - UECE, Dr. Silas Munguba Av., 1700, Itaperi Campus, CEP 60.714-903, Fortaleza-CE, Brazil. E-mail: nibotanica@gmail.com

${ }^{3} \mathrm{PhD}$ in Agronomy, Adjunct Professor of the Biological Sciences Course, CCS / UECE, Fortaleza-CE, Brazil. E-mail: eliseulucena@ uece.br

${ }^{4} \mathrm{PhD}$ in Ecology, Associete Professor of the Biological Sciences Course, CCS/UECE, Fortaleza-CE, Brazil. E-mail: oriel.herrera@uece.br ${ }^{5}$ Master in Food Science and Technology, Analyst of the Laboratory of Post-Harvesting Physiology and Technology, Embrapa Agroindústria Tropical, Fortaleza-CE, Brazil. E-mail: marcia.silveira@embrapa.br 


\section{INTRODUCTION}

Fruit consumption has been associated with a decrease in cardiovascular and cancerous diseases, and this effect is promising due to the presence of antioxidants, which neutralize reactive species or free radicals, thus reducing oxidative damage in cell metabolism (SOUZA et al. 2014).

In order to understand the bioavailability of antioxidants and the functions of phenols of plant origin in the human body, it is important to determine their quantity and chemical structures (KOOLEN et al., 2013, BATAGLION et al., 2014, CARVALHOSILVA et al., 2014 BATAGLION et al., 2015, BERTO et al., 2015).

The frequency and development of chronic diseases are partly due to the imbalance of functional components in the biological parameters, among which phenolic compounds, carotenoids, flavonoids, anthocyanins, terpenes, vitamin $\mathrm{C}$ and other phytochemicals present in almost all fruits found in Brazilian fruit species. In addition, substances contained in fruits can be responsible for the protection of cells, prevention of infections and diseases, providing sustainability, maintenance of recovery and compensatory metabolisms, such as antioxidant function (ROCHA et al., 2013).

Recently, natural antioxidants from medicinal plants have been intensively investigated in order to discover compounds capable of protecting from diseases related to oxidative stress and damage induced by free radicals. In this sense, polyphenolics have gained importance due to their potential as prophylactic and therapeutic agents in many diseases; therefore, many studies have been conducted by the scientific community reporting their antioxidant effects (KINDL et al., 2015).

The aim of this study was to quantify polyphenolic compounds and the antioxidant activity of four native fruits of the coast of Ceará at different maturation stages, myrtle (Eugenia punicifolia (Kunth) DC), guajiru (Chrisobalanus icaco L.), manipuçá (Mouriri cearensis Huber) and muricipitanga (Byrsonima gardneriana A. Juss.), aiming at their use for a healthier diet.

\section{MATERIAL AND METHODS}

The work was carried out at the Laboratory of Plant Ecophysiology, State University of Ceará - UECE, and at the Laboratory of Post-Harvest Physiology and Technology, Embrapa Agroindústria Tropical, both in Fortaleza-CE, from February 2013 to November 2014.

Vouches specimens of guajiru - Chrysobalanus icaco L. (57408), manipuçá - Mouriri cearensis Huber (57407), murici-pitanga - Byrsonima gardneriana A. Juss. (57409) and myrtle - Eugenia punicifolia (Kunth) DC. (57410) were found deposited in the Prisco Bezerra Herbarium, Federal University of Ceará - UFC, Fortaleza-CE.

Myrtle fruits were collected in the State Botanical Park of Ceará, Caucaia-CE, whose coordinates are $3^{\circ} 44^{\prime} 10^{\prime \prime} \mathrm{S}$ and $38^{\circ} 39^{\prime} 11^{\prime \prime} \mathrm{W}$, consisting of sandbanks, Caatinga and mangrove forests, with minimum precipitation from August to October $(0.0 \mathrm{~mm})$ and maximum in May $(157.4 \mathrm{~mm})$ (FUNCEME / IPECE, 2015), and equatorial climate of Savannah with dry summer (As), according to the Köppen-Geiger climatic classification ( KOTTEK et al., 2006).

Guajiru, manipuçá and murici-pitanga fruits were collected from the Botanical Garden of São Gonçalo, São Gonçalo do Amarante-CE, located in coordinates $3^{\circ} 36^{\prime}$ ' $26^{\prime}$ 'S and $38^{\circ} 58^{\prime}$ ' $06^{\prime}$ "W, consisting of sandbanks, with minimum precipitation in August $(1.5 \mathrm{~mm})$ and maximum in April $(281.8 \mathrm{~mm})$ (FUNCEME / IPECE, 2015), and equatorial climate of Savannah with dry summer (As), according to the Köppen-Geiger climatic classification of (KOTTEK et al., 2006).

Fruits of the four species native to the coast of Ceará were manually and randomly collected from 10 previously selected plants of each plant species, approximately $2.5 \mathrm{~kg}$ of fruits per maturation stage. Guajiru, manipuçá, murici-pitanga and myrtle were characterized in the following stages (E), respectively: 5 ( $\mathrm{E}_{1}$-very immature, $\mathrm{E}_{2}$-immature, $\mathrm{E}_{3}$-mature, E4-ripe and E5-senescent), 5 ( $\mathrm{E}_{1}$-very immature, $\mathrm{E}_{2}$-immature, $\mathrm{E}_{3}$-mature, $\mathrm{E}_{4}$-ripe, and $\mathrm{E}_{5}$ senescent) and 6 ( $\mathrm{E}_{1}$-very immature, $\mathrm{E}_{2}$-moderately immature, $\mathrm{E}_{3}$-immature, $\mathrm{E}_{4}$-mature, $\mathrm{E}_{5}$-ripe and $\mathrm{E}_{6}$-senescent).

Initially, seeds were removed from fruits, and the pulp was processed and frozen in freezer at $-20^{\circ} \mathrm{C} \pm 1$, to finally analyze the total extractable polyphenols (POL) and total antioxidant activity (AAT).

POLs were determined using the FolinCiocalteau reagent and a standard curve of gallic acid as reference, according to methodology described by Larrauri; Rupérez; Saura-Calixto (1997).

AAT was determined by assay with free radical ABTS described by Rufino et al. (2007).

The experimental design was a completely randomized design, with five or six treatments, depending on the maturation stage of fruits, and 
four replicates consisting of 200 fruits each. Results were submitted to analysis of variance, observing the significance by the F test and, when significant, the Tukey test was carried out, at the $5 \%$ probability level, using the $<$ V.1.0 $>$ - ESTAT Statistical Analysis System. To verify the linear correlations among variables, significance was verified by the $t$ test, using the Assistat 7.7 beta statistical software.

\section{RESULTS AND DISCUSSION}

The results obtained for total extractable polyphenols (POL) at the different maturation stages of fruits (Figure 1) presented the following values: in guajiru fruits, minimum of $10.90 \mathrm{mg} /$ $100 \mathrm{~g}$ in $\mathrm{E}_{4}$ and maximum of $480.73 \mathrm{mg} / 100 \mathrm{~g}$ in $\mathrm{E}_{3}$; in manipuçá fruits, minimum of $18.28 \mathrm{mg} / 100$ $\mathrm{g}$ in $\mathrm{E}_{1}$ and maximum of $94.91 \mathrm{mg} / 100 \mathrm{~g}$ in $\mathrm{E}_{4}$; in murici-pitanga fruits, minimum of $153.51 \mathrm{mg} / 100 \mathrm{~g}$ in $\mathrm{E}_{3}$ and maximum of $373.98 \mathrm{mg} / 100 \mathrm{~g}$ in $\mathrm{E}_{2}$; and in myrtle fruits, minimum of $75.51 \mathrm{mg} / 100 \mathrm{~g}$ in $\mathrm{E}_{6}$ and maximum of $180.68 \mathrm{mg} / 100 \mathrm{~g}$ in $\mathrm{E}_{2}$.

Analyzing POLs obtained from viuvinha fruits (Myrcia splendens (Sw.) DC.), Façanha (2012) obtained maximum of $415 \mathrm{mg} / 100 \mathrm{~g}$ no $\mathrm{E}_{2}$ and in the case of mapirunga fruits, maximum of $414.61 \mathrm{mg}$ / 100 was obtained in $\mathrm{E}_{1}$; therefore, these values were higher than the maximum values obtained in myrtle fruits in this study $\left(\mathrm{E}_{2}-180,68 \mathrm{mg} / 100 \mathrm{~g}\right)$.

Silveira (2008) analyzed POLs among 15 genotypes of mature puçá fruits (Mouriri elliptica Mart.), and genotype 14 presented the lowest value, $71.35 \mathrm{mg} / 100 \mathrm{~g}$, and genotypes 17 and E2 obtained the highest values, $180.45 \mathrm{mg} / 100 \mathrm{~g}$ and $179.95 \mathrm{mg}$ / $100 \mathrm{~g}$, respectively; the lowest result reported by the author was lower than the mature manipuçá fruit analyzed in this study $\left(\mathrm{E}_{4}-94.91 \mathrm{mg} / 100 \mathrm{~g}\right)$, while the highest values reported were higher.

For the total antioxidant activity (AAT), the results obtained in the different maturation stages of the four native fruits analyzed are described according to Figure 2. In guajiru fruits, minimum of $1.45 \mu \mathrm{M}$ Trolox / $\mathrm{g}$ in $\mathrm{E}_{5}$ and maximum of 20.20 $\mu \mathrm{M}$ Trolox / $\mathrm{g}$ in $\mathrm{E}_{4}$; in manipuçá fruits, minimum of $9.28 \mu \mathrm{M}$ Trolox / $\mathrm{g}$ in $\mathrm{E}_{2}$ and maximum of $42.99 \mu \mathrm{M}$ Trolox / $\mathrm{g}$ in $\mathrm{E}_{1}$; in murici-pitanga fruits, minimum of $4.42 \mu \mathrm{M}$ of Trolox / $\mathrm{g}$ in $\mathrm{E}_{3}$ and maximum of $7.40 \mu \mathrm{M}$ of Trolox / $\mathrm{g}$ in $\mathrm{E}_{2}$; and in myrtle fruits, minimum of $6.69 \mu \mathrm{M}$ of Trolox / $\mathrm{g}$ in $\mathrm{E}_{5}$ and maximum of 18.46 $\mu \mathrm{M}$ of Trolox / $\mathrm{g}$ in $\mathrm{E}_{2}$.

Studying the AAT of 15 genotypes of mature puçá fruits, Silveira (2008) found that genotype E1 presented lower value, $9.10 \mu \mathrm{M}$ Trolox / g, and genotype 2 presented higher value, $26.49 \mu \mathrm{M}$ Trolox
/ $\mathrm{g}$; therefore, the lower result reported by the author was lower than mature manipuçá fruits in this study $\left(\mathrm{E}_{4}-14.08 \mu \mathrm{M}\right.$ Trolox $/ \mathrm{g}$ ), while the highest reported value was higher.

Studying the AAT of the pulp of mature Amazon fruits, including murici (Byrsonima crassifolia), Canuto et al. (2010) obtained value of $1.5 \mu \mathrm{M}$ Trolox / g, which is lower than the value found for mature Murici-pitanga fruits in this study $\left(\mathrm{E}_{4}-6.16 \mu \mathrm{M}\right.$ Trolox /g).

Evaluating the AAT of mature murici fruits (Byrsonima verbascifolia), Morais et al. (2013) obtained value of $15.63 \mu \mathrm{M}$ Trolox / g, which is higher than that obtained in mature murici-pitanga fruits in this work $\left(\mathrm{E}_{5}-7.06 \mu \mathrm{M}\right.$ Trolox / g).

Analyzing the AAT of mature uvaia fruits (Eugenia pyriformis Cambess), Pereira et al. (2012) obtained value of $336.29 \mu \mathrm{M}$ Trolox / g, therefore it presents higher antioxidant potential compared to mature myrtle fruits in this work $\left(\mathrm{E}_{5}-6.69 \mu \mathrm{M}\right.$ Of Trolox / g).

In this study, a correlation was observed between the same species only for guajiru fruits (Table 1). A negative and significant correlation was obtained at 5\% probability level between POLs and AAT, with $\mathrm{R}=-0.95$. On the other hand, negative and significant correlations were observed among different species: GPOL and MPPOL $(\mathrm{R}=-0.99, \mathrm{P}$ $<0.01)$; GPOL and MUPOL $(\mathrm{R}=-0.99, \mathrm{P}<0.01)$; MPPOL and MUPOL $(\mathrm{R}=-0.96, \mathrm{P}<0.05)$; GAAT and MUAAT $(\mathrm{R}=-0.95, \mathrm{P}<0.05)$; MPAAT and MUAAT $(\mathrm{R}=-0.99, \mathrm{P}<0.01)$; as well as positive and significant correlations: MPPOL and GAAT (R $=0.98, \mathrm{P}<0.05)$; GAAT and MPAAT $(\mathrm{R}=0.98, \mathrm{P}$ $<0.05$ ).

Analyzing 15 genotypes of puçá fruits, Silveira (2008) verified a positive and significant correlation at $1 \%$ probability level between POLs and $\operatorname{AAT}(\mathrm{R}=0.66, \mathrm{P}<0.01)$; however, this behavior was not observed for manipuçá fruits in this study, since it did not present any significant correlation.

Kuskoski et al. (2006) verified a positive and significant correlation in 15 tropical fruits at $1 \%$ probability level between POLs and AAT, with $\mathrm{R}=$ 0.99 , which differs from that obtained among these variables in guajiru fruits studied in this study $(\mathrm{R}=$ $-0.95, \mathrm{P}<0.05)$.

Similarly, working with pure cupuaçu pulps, Santos (2007) found a positive and significant correlation between POLs and AAT $(\mathrm{R}=0.74, \mathrm{P}$ $<0.05$ ), which also differs from results of this study for guajiru fruits. 


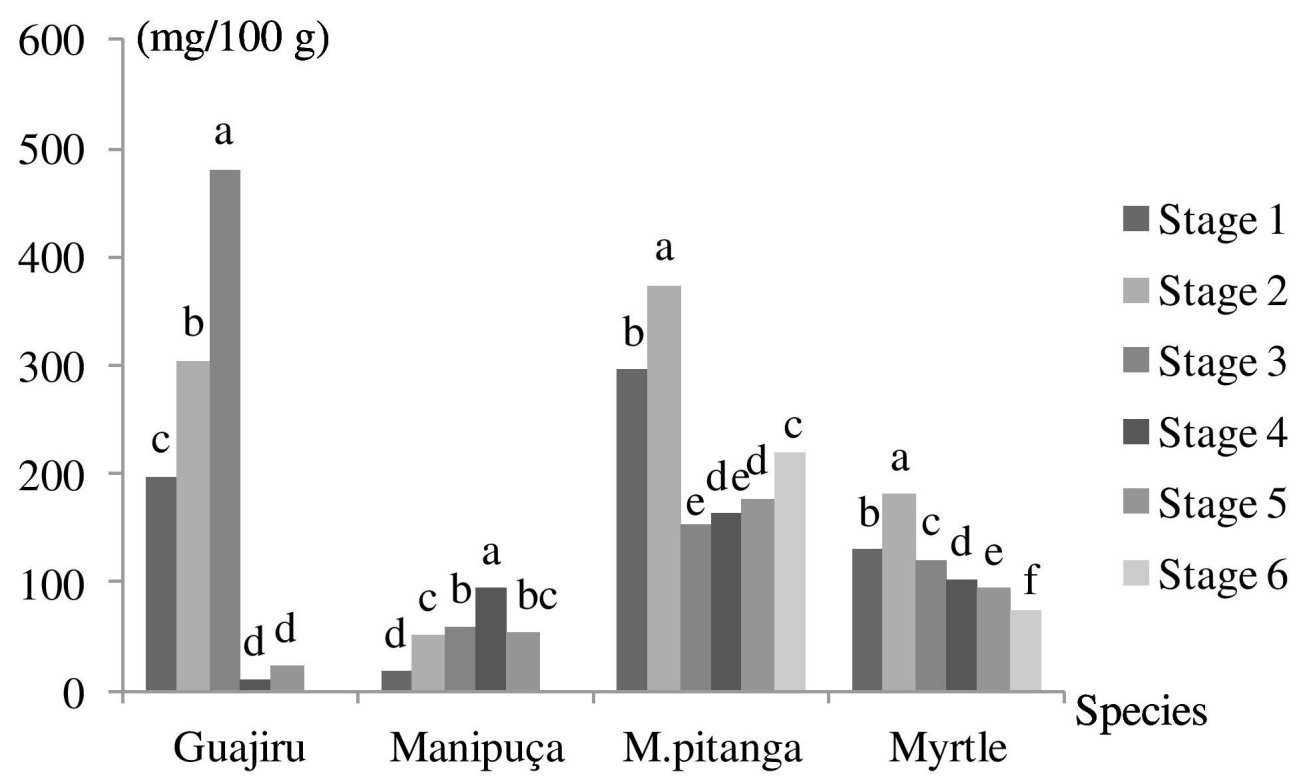

FIGURE 1 - Total extractable polyphenols (mg / 100 g) of guajiru (Chrysobalanus icaco L.), manipuçá (Mouriri cearensis Huber), murici-pitanga (Byrsonima gardneriana A. Juss.) and myrtle fruits (Eugenia punicifolia (Kunth) DC.) at different maturation stages.

Means followed by the same letter in the same species do not differ from each other by the Tukey test at 5\% probability level.

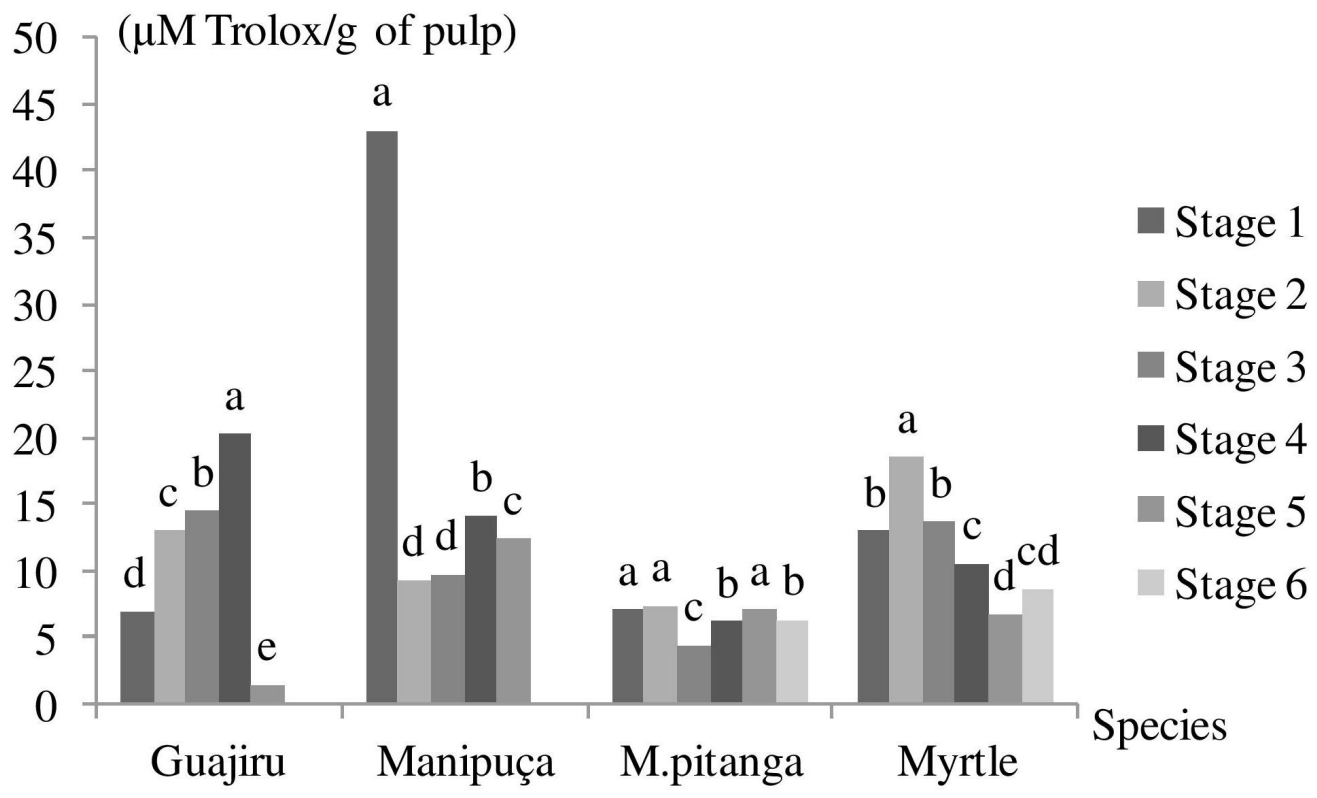

FIGURE 2 - Total antioxidant activity ( $\mu \mathrm{M}$ Trolox / g) of guajiru (Chrysobalanus icaco L.), manipuçá (Mouriri cearensis Huber), murici-pitanga (Byrsonima gardneriana A. Juss.) and myrtle fruits (Eugenia punicifolia (Kunth) DC.) at different maturation stages.

Means followed by the same letter, in the same species, do not differ from each other by the Tukey test at $5 \%$ probability level. 
TABLE 1 - Correlation matrix between total extractable polyphenol (POL) and total antioxidant activity (AAT) of guajiru (G), manipuçá (M), murici-pitanga (MP) and myrtle (MU) fruits at different maturation stages.

\begin{tabular}{cccccccc}
\hline Variables & MPOL & MPPOL & MUPOL & GAAT & MAAT & MPAAT & MUAAT \\
\hline GPOL & $0.39^{\text {ns }}$ & $-0.99^{* *}$ & $-0.99^{* *}$ & $-0.95^{*}$ & $-0.00^{\text {ns }}$ & $-0.89^{\text {ns }}$ & $0.83^{\text {ns }}$ \\
MPOL & - & $-0.51^{\text {ns }}$ & $-0.27^{\text {ns }}$ & $0.64^{\text {ns }}$ & $0.91^{\text {ns }}$ & $-0.76^{\text {ns }}$ & $0.83^{\text {ns }}$ \\
MPPOL & - & - & $-0.96^{*}$ & $0.98^{*}$ & $-0.13^{\text {ns }}$ & $0.94^{\text {ns }}$ & $-0.89^{\text {ns }}$ \\
MUPOL & - & - & - & $0.91^{\text {ns }}$ & $0.12^{\text {ns }}$ & $0.83^{\text {ns }}$ & $-0.75^{\text {ns }}$ \\
GAAT & - & - & - & - & $-0.29^{\text {ns }}$ & $0.98^{*}$ & $-0.95^{*}$ \\
MAAT & - & - & - & - & - & $-0.44^{\text {ns }}$ & $0.55^{\text {ns }}$ \\
MPAAT & - & - & - & - & - & - & $-0.99^{* *}$ \\
\hline
\end{tabular}

*, ** Significant, respectively, at 5 and $1 \%$ of probability level, by the $\mathrm{t}$ test.

${ }^{n s}$ Not significant.

\section{CONCLUSIONS}

Among the maturation stages of the four fruits studied, stage 3 for guajiru fruits, stage 4 for manipuçá fruits, stage 2 for murici-pitanga fruits and stage 2 for myrtle fruits showed the highest polyphenolic values when compared to the other stages, although guajiru fruits stood out, which presented the highest value.

For the antioxidant activity, maturation stage 1 of manipuçá fruits stood out, as it presented the highest antioxidant content among the fruits studied, although this stage had the lowest polyphenolic content, which suggests the action of other antioxidants, such as vitamins $\mathrm{C}$ and $\mathrm{E}$, chlorophyll and carotenoids. However, relevant values were also obtained at maturation stage 4 for guajiru fruits, maturation stage 2 for myrtle fruits and maturation stage 2 for murici-pitanga fruits.

For the antioxidant activity, maturation stage 1 for manipuçá fruits stood out, as it presented the highest antioxidant content among the fruits studied; however, relevant values were also obtained at maturation stage 4 for guajiru fruits, maturation stage 2 for myrtle fruits and maturation stage 2 for murici-pitanga fruits.

Guajiru and manipuçá fruits can be used for a healthier diet, since guajiru has the highest polyphenolic values, and manipuçá, the highest antioxidant activity; therefore, both can be recommended to be commercially exploited by the food industry.

\section{ACKNOWLEDGMENTS}

To the Foundation for Scientific and Technological Development (FUNCAP) of Ceará for granting the Master's Degree scholarship to the first author; the National Council for Scientific and Technological Development (CNPq) and Banco do Nordeste (BNB), for the financial support to the research project; Embrapa Agroindústria Tropical, for technical support; the Botanical State Park of Ceará and to the Botanic Garden of São Gonçalo, for the logistical support.

\section{REFERENCES}

BATAGLION, G. A.; SILVA, F. M. A.; EBERLIN, M. N.; KOOLEN, H. H. F. Simultaneous quantification of phenolic compounds in buriti fruit (Mauritia flexuosa L.f.) by ultra-high performance liquid chromatography coupled to tandem mass spectrometry. Food Research International, Barking, v.66, p.396-400, 2014.

BATAGLION, G. A.; SILVA, F. M. A.; EBERLIN, M. N.; KOOLEN, H. H. F. Determination of the phenolic composition from Brazilian tropical fruits by UHPLC-MS/MS. Food Chemistry, Reading, v.180, p.280-287, 2015. 
BERTO, A.; RIBEIRO, A. B.; SOUZA, N. E.; FERNANDES, E.; CHISTÉ, R. C. Bioactive compounds and scavenging capacity of pulp, peel and seed extracts of the Amazonian fruit Quararibea cordata against ROS and RNS. Food Research International, Barking, v.72, p.1-7, 2015.

CANUTO, G. A. B.; XAVIER, A. A. O.; NEVES, L. C.; BENASSI, M. T. Caracterização físico-química de polpas de frutos da Amazônia e sua correlação com a atividade anti-radical livre. Revista Brasileira de Fruticultura, Jaboticabal, v.32, n.4, p.1196-1205, 2010.

CARVALHO-SILVA, L. B.; DIONÍSIO, A. P.; PEREIRA, A. C. S.; WURLITZER, N. J.; BRITO, E. S.; BATAGLION, G. A.; BRASIL, I. M.; EBERLIN, M. N.; LIU, R. H. Antiproliferative, antimutagenic and antioxidant activities of a Brazilian tropical fruit juice. LWT — Food Science and Technology, Athens, v.59, p.1319-1324, 2014.

FAÇANHA, R. V. Qualidade e potencial antioxidante de frutas nativas do litoral cearense em diferentes estágios de maturação. 2012. $97 \mathrm{f}$. Dissertação (Mestrado em Agronomia) - Programa de Pós-Graduação em Agronomia/Fitotecnia, Universidade Federal do Ceará, Fortaleza, 2012.

FUNCEME - Fundação Cearense de Meteorologia e Recursos Hídricos. Disponível em: <http://www. funceme.br/app/calendario/produto/municipios/ maxima/diario?data $=2015-2-3>$. Acesso em: 25 jan. 2015.

IPECE- Instituto de Pesquisa e Estratégia Econômica do Ceará. Disponível em: $<$ http://www.ipece.ce.gov. br/publicacoes/perfil_basico/index_perfil_basico. htm>. Acesso em: 25 jan. 2015.

KINDL, M.; BLADEKOVIT, B.; BUCAR, F.; VLADIMIR-KNEDEVIT, S. Antioxidant and anticholinesterase potential of six Thymus species. Evidence-Based Complementary and Alternative Medicine, New York, v.2015, p.1-10, 2015.

KOOLEN, H.H.F.; SILVA, F.M.A.; GOZZO, F.C.; SOUZA, A.Q.L.; SOUZA, A.D.L. Antioxidant, antimicrobial activities and characterization of phenolic compounds from buriti (Mauritia flexuosa L.f.) by UPLC-ESI-MS/MS. Food Research International, Barking, v.51, p.467-473, 2013.
KOTTEK, M.; GRIESER, J.; BECK, C.; RUDOLF, B.; RUBEL, F. World map of Köppen-Geiger climate classification updated. Meteorologische Zeitschrift, Berlin, v.15, n.3, p.259-263, 2006.

KUSKOSKI, E.M.ASUERO, A.G.; MORALES, M.T.; FETT, R. Frutos tropicais silvestres e polpas de frutas congeladas: atividade antioxidante, polifenóis e antocianinas. Ciência Rural, Santa Maria, v.36, n.4, p.1283-1287, 2006.

LARRAURI, J.A.; RUPÉREZ, P.; SAURACALIXTO, F. Effect of drying temperature on the stabilitity of polyphenols and antioxidant activity of red grape pomace peels. Journal Agriculture and Food Chemistry, Washington, v.45, p.1390-1393, 1997.

MORAIS, M.L.; SILVA, A.C.R.; ARAÚJO, C.R.R.; ESTEVES, E.A.; DESSIMONI-PINTO, N.A.V. Determinação do potencial antioxidante in vitro de frutos do Cerrado brasileiro. Revista Brasileira de Fruticultura, Jaboticabal, v.35, n.2, p.355-360, 2013.

PEREIRA, M.C.; STEFFENS, R.S.; JABLONSKI, A.; HERTZ, P.F.; RIOS, A de O.; VIZZOTO, M.; FLORES, S.H. Characterization and antioxidant potential of Brazilian fruits from the Myrtaceae Family. Journal of Agricultural and Food Chemistry, Washington, v.60, n.12, p.3061-3067, 2012.

ROCHA, M.S.; FIGUEIREDO, R.W.; ARAÚJO, M.A.M.; MOREIRA-ARAÚJO, R.S.R. Caracterização físico-química e atividade antioxidante (in vitro) de frutos do Cerrado piauiense. Revista Brasileira de Fruticultura, Jaboticabal, v.35, n.4, p.933-941, 2013.

RUFINO, M. S. M.; ALVES, R. E.; DE BRITO, E. S.; DE MORAIS, S. M.; SAMPAIO, C. G.; PÉREZ-JIMENEZ, J.; SAURA-CALIXTO, F. D. Metodologia científica: Determinação da atividade antioxidante total em frutas pela captura do radical livre ABTS •+. Fortaleza: Embrapa Agroindústria Tropical, 2007. 4 p. (Comunicado Técnico). 
SANTOS, G. M. dos. Contribuição da vitamina C, carotenoides e compostos fenólicos no potencial antioxidante de produtos comerciais de açaí e cupuaçu. 2007. 99 f. Dissertação (Mestrado em Tecnologia de Alimentos) - Universidade Federal do Ceará, Fortaleza, 2007.

SILVEIRA, M.R.S. da. Qualidade e atividade antioxidante de frutos de genótipos de puçazeiro "Coroa de Frade" (Mouriri elliptica Mart.) da vegetação litorânea do Ceará. 2008. 117 f. Dissertação (Mestrado em Tecnologia de Alimentos) - Universidade Federal do Ceará, Fortaleza, 2008.
SOUZA, K.O.; MOURA, C.F.H.; BRITO, E.S; MIRANDA, M.R.A. Antioxidant compounds and total antioxidant activity in fruits of acerola from $\mathrm{cv}$. Flor Branca, Florida Sweet and BRS 366. Revista Brasileira de Fruticultura, Jaboticabal, v. 36, n. 2, p. 294-304, 2014. 